\title{
術後耳下腺癌と診断された症例の再手術
}

$\begin{array}{rrrr}\text { 桜井 } & \text { 一生 } \cdot \text { 竹内 } & \text { 健二 } \cdot \text { 小森 } & \text { 克彦 } \\ \text { 加藤 } & \text { 久幸 } \cdot \text { 齋藤 } & \text { 正治 } \cdot \text { 岡田 } & \text { 達佳 } \\ \text { 旭 } & \text { 宏・伊藤 } & \text { 周史 } \cdot \text { 内藤 } & \text { 健晴 }\end{array}$

\section{Clinical Study of Reoperation for Parotid Cancer}

\author{
Kazuo Sakurai, Kenji Takeuchi, Katsuhiko Komori, \\ Hisayuki Kato, Syoji Saito, Tatsuyoshi Okada, \\ Hiroshi Asahi, Chikashi Ito and Kensei Naito \\ (Fujita Health University School of Medicine)
}

1. Five cases of parotid cancer are reported, in which the patients underwent parotidectomy under diagnosis of benign tumor in another hospital or department, were postoperatively diagnosed with malignant tumor, and then received reoperation in our department.

2. The age and sex distribution of the cases was 3 males and 2 females with a mean age of 40 years, ranging from 10 to 77 years, including 2 child cases under 15 years.

3. Histopathologically, the cancer was classified as adenoid cystic carcinoma in 2 cases, mucoepidermoidcarcinoma in 2 cases, and acinic cell carcinoma in 1 case, and one each of adenoid cystic carcinoma and mucoepidermoid carcinoma occurred in the children.

4. The patients underwent reoperation within 8 weeks after the first surgery. The surgical technique was total parotidectomy in 1 case and superficial lobectomy in the remaining 4 cases, with the facial nerve being preserved in all 5 patients.

5. Palpation in the examinations conducted at follow-up in our department detected no localized tumor remnant, but the tumor was still found to be histologically residual in 4 of the 5 cases.

6. The postoperative clinical course was found to be excellent, without recurrence or metastasis of the cancer.

Key words : reoperation, parotid cancer, secondary case

\section{はじめに}

耳下腺癌症例のなかには, 非浸潤性の小腫瘤で周囲組 織との癒着むなく，触診上良性腫瘍との鑑別が困難な例 もあり, 耳下腺の良性腫瘍あるいは耳下部のリンパ節, 皮下腫瘤として摘出され，術後の病理診断で耳下腺癌と 診断されるものも少なからず認められる。 このような症 例に対して追加治療を行うべきかどうか, 行うとしたら どのような治療を行うのか，選択に苦慮することも少な くない，そこで今回われわれは，他院あるいは他科で良
性腫瘤として摘出術を受け術後に耳下腺癌と診断され, 当科で再手術を行った耳下腺癌の 5 症例を経験したので 報告する。

\section{対象症例および結果}

対象症例は1978年以後当科で摘出術を行った耳下腺癌 2 次症例のうち, 初回手術時に他院, 他科にて耳下腺あ るいは耳下部良性腫瘍として摘出術を受け，術後の病理 組織検查にて耳下腺癌と診断された症例で，いずれも初 
表 1 症例

\begin{tabular}{c|c|c|l|c|c|c|c}
\hline \hline 症例 & 年齢 & 性 & 病理組織型 & 再手術までの期間 & 治療法 & 腫瘍の残存 & 予後 \\
\hline 1 & 55 & 女 & 腺様囊胞癌 & 4 週 & 全摘 & $(+)$ & 生存 176 力月 \\
2 & 10 & 男 & 粘表皮癌 & 8 週 & 浅葉切除 & $(+)$ & 生存 135 カ月 \\
3 & 77 & 男 & 腺房細胞癌 & 4 週 & 浅葉切除 & $(+)$ & 生存 117 月 \\
4 & 14 & 女 & 腺様囊胞癌 & 3 週 & 浅葉切除 & $(-)$ & 生存 108 カ月 \\
5 & 43 & 男 & 粘表皮癌 & 3 週 & 浅葉切除 & $(+)$ & 生存 66 力 月
\end{tabular}

回手術より 1カ月以内に当科に紹介された 5 症例である （表 1).いずれの症例も当科初診時には触診上局所に明 らかな腫瘍の残存はなく, 頸部リンパ節転移, 遠隔転移 も認めなかった。

年齢は $10 \sim 77$ 歳で, 平均年齢は 40 歳であったが, 15 歳以下の小児例が 2 例認められた. 性別は男性 3 例, 女 性 2 例であった。病理組織型は, 腺様囊胞癌 2 例, 粘表 皮癌 2 例, 腺房細胞癌 1 例であり, 腺様囊胞癌の 1 例と 粘表皮癌の 1 例は小児例であった。

初回手術から再手術までの期間は，3〜8 週で 5 例中 4 例は 4 週以内に再手術を行った. 再手術の術式は初回 手術時の腫瘍の局在および大きさ, 浸潤の程度により決 定したが，原発部位はいずれも耳下腺浅葉と推測され， $40 \mathrm{~mm}$ 大の大きさであった腺様囊胞癌の 1 例は顔面神経 を温存し耳下腺全摘術を行ったが，ほかの 4 例は $20 \mathrm{~mm}$ 以下の大きさであったため顔面神経を温存し浅葉切除術 を行った. 5 例中 4 例に摘出した浅葉内に腫瘍細胞の残 存を認めたが, 術後 $66 \sim 176$ 力月経過した現在, 全例再 発，転移を認めていない.

術前に 5 例中 4 例に CT 検査を, 3 例に超音波検查（以 下 US と略す）を行ったが，術後の病理組織検查にて腫 瘍細胞の残存を認めた 4 例中 2 例はエコー（US）にて腫 瘍の残存を強く疑ら所見を認めた。 CT 検査では異常陰 影を 2 例に認めたが, 初回手術後の変化との鑑別は困難

表 2 診断

\begin{tabular}{c|c|c|c|c}
\hline \hline 症例 & 残存 & 触診 & US & CT \\
\hline 1 & + & - & + & \pm \\
2 & + & - & + & - \\
3 & + & - & 施行せず & \pm \\
4 & - & - & \pm & - \\
5 & + & - & 施行せず & 施行せず
\end{tabular}

（+）腫瘍を認める

（土）腫瘍が疑われる

（一）腫瘍を認めない
であった（表 2).US で腫瘍の残存ありと診断できた 2 例を病理組織像とともに呈示する（図 1，2）.

\section{考 察}

耳下腺腫瘍の診断は, 触診, US, CT, MRI, 穿刺吸引 細胞診（以下 FNA と略す）などを用いて行われる.耳下 腺腫瘍を取り扱う機会の多いわれわれ耳鼻咽喉科・頭頸 部外科医にとって，一般にその診断はさほど難しいもの ではない，特に画像診断の発達に伴い，耳下部，耳前部 の腫瘤が耳下腺内に発生したものかどうかの診断は，耳 下腺被膜直下から外方性に発育する腫瘍以外は比較的容 易に診断可能と思われる。しかし，耳下腺腫瘍の診断に 不慣れな他科の医師にとっては耳下腺腫瘍と診断するの は必ずしも容易ではなく，リンパ節や皮下腫瘤として生 検や摘出術が行われることも少なくない. 質的診断は US, CT, MRI などの画像診断を用いても非浸潤性腫瘍で の良性，悪性の診断は難しく，特に $20 \mathrm{~mm}$ 以下の小さな 腫瘍では困難なことが多いと思われる112). 最近では FNA が行われることが多くなり診断率は向上したが，耳下腺 腫瘍では組織型が多彩なことや，低悪性の腫瘍が存在す ることなどにより，その正診率は $60 \sim 80 \%$ 前後にとど まっているのが現状である ${ }^{3)}$ ） . 自験例 5 例中前医で耳 下腺腫瘍と診断されていたのは耳鼻咽喉科医を受診して いた 2 例のみであり，ほかの 3 例は他疾患として手術を 受けていた. 3 例とも初回手術時の腫瘍の大きさは $20 \mathrm{~mm}$ 以下の表在性の腫瘍であったものと思われ，摘出した腫 瘍の病理組織検査で耳下腺癌と診断された症例である. 耳鼻咽喉科を受診した2例のうち1例はFNAが行われて いたが，結果は陰性であり術前には耳下腺多形腺腫と診 断され浅葉部分切除術が行われていた。 ほかの 1 例は FNAは行われておらず術前診断は耳下腺良性腫瘍であっ た. 耳下部，耳前部の腫瘤の診断には，少なくとも US と FNA を行い, 耳下腺腫瘍の可能性があるかどうか, 覀 性所見があるかどうかは術前に検査すべきと考える. 


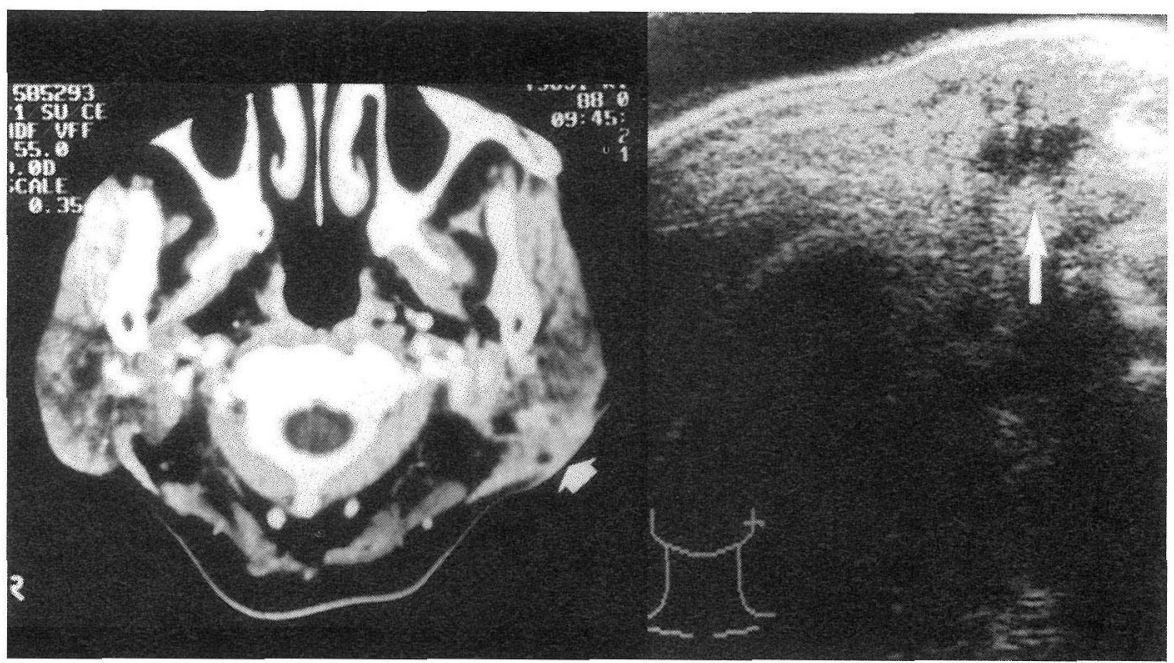

a
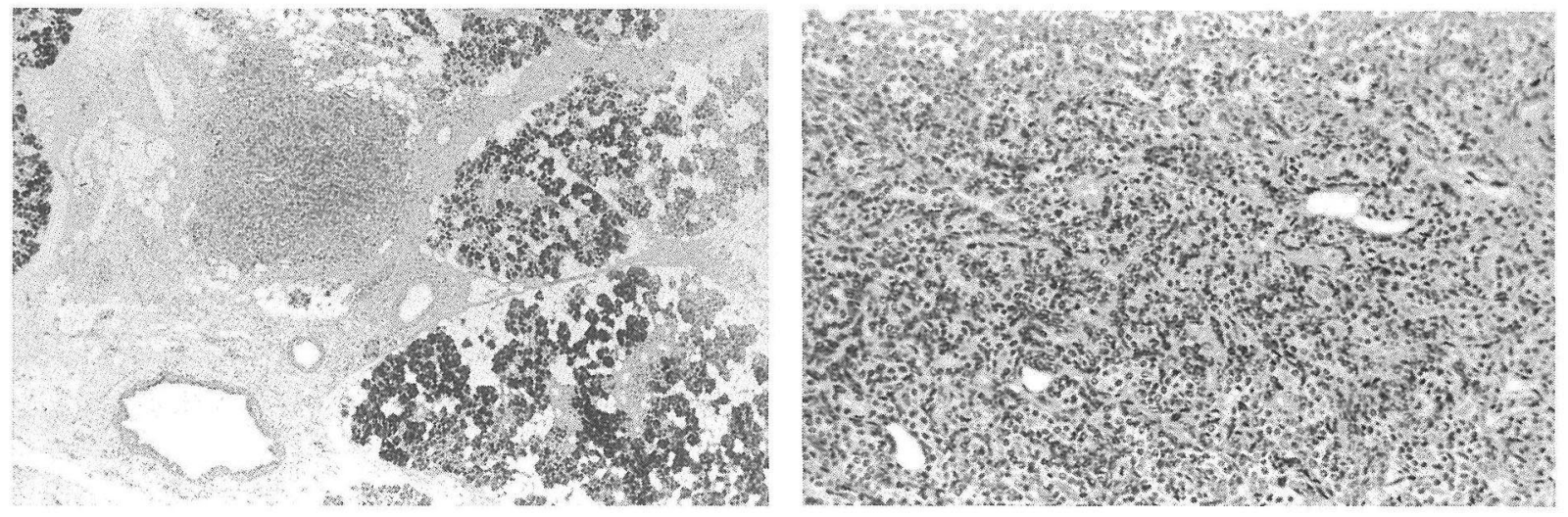

b

図 1 症例 1

$\mathrm{a}$ ：画像所見（左：CT，右：US）

左：耳下部皮下に境界不明膫な high density mass を認める。

右：皮下に境界不明瞭な hypoechoic mass を認める。

$\mathrm{b}$ : 病理組織像 (HE 染色. 左 : 弱拡大, 右 : 強拡大)

左 : 腫瘍組織残存を認める.

右：充実性に増生する腫湯細胞を認める.

今回の対象症例のように術後に耳下腺癌と診断された 場合，追加切除をするべきかどうかは議論のあるところ であるが，鮫島ら ${ }^{6)}$ は，術前，術中所見では浸潤性増殖 を認めず，術後病理組織にて悪性と判明した 13 例中 12 例は耳下腺部分切除のみを行い経過観察を行った結果, T2aの8例中1例と, T3aの3例中2例に局所再発がみられ， その病理組織は腺癌 2 例, 扁平上皮癌 1 例であったとし, 再発した 3 例は追加切除が必要であったと述べている. また安松ら7)も $\mathrm{T} 1$ から T3 症例の 10 例に良性腫瘍とし
て核出，葉部分切除を行い，このうち 3 例に局所再発を きたしたとし, T2 症例で葉切除以上の手術を行っていな い症例には何らかの追加治療が必要と述べている。鮫島 $ら^{6)}$ ，安松ら 7) の報告と自験例との違いは，自験例は他 院，他科で手術が行われており術中所見が不明な点と 5 例中 3 例は核出術が行われていた点である。われわれは 自験例 5 例中 4 例に腫瘍の残存を認めたことから術前, 術中所見の明らかでない場合は再手術を行らべきと考え る。その際どのような術式を選択するかは意見の分かれ 


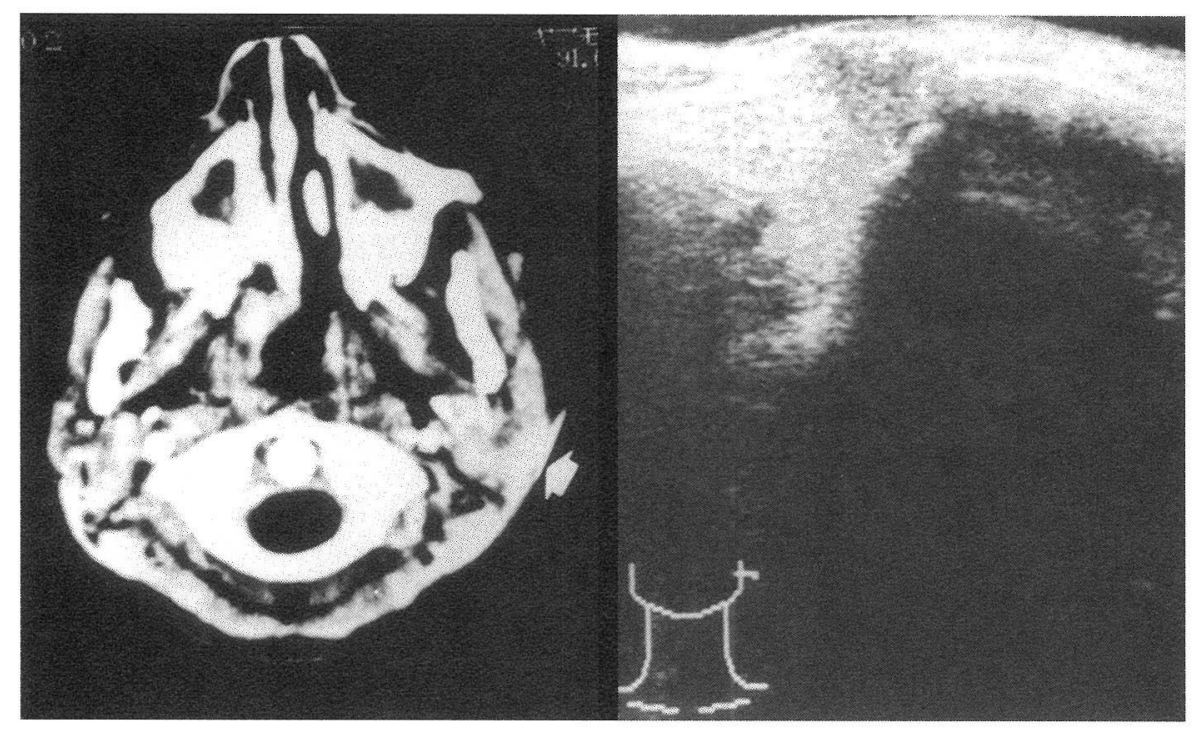

a
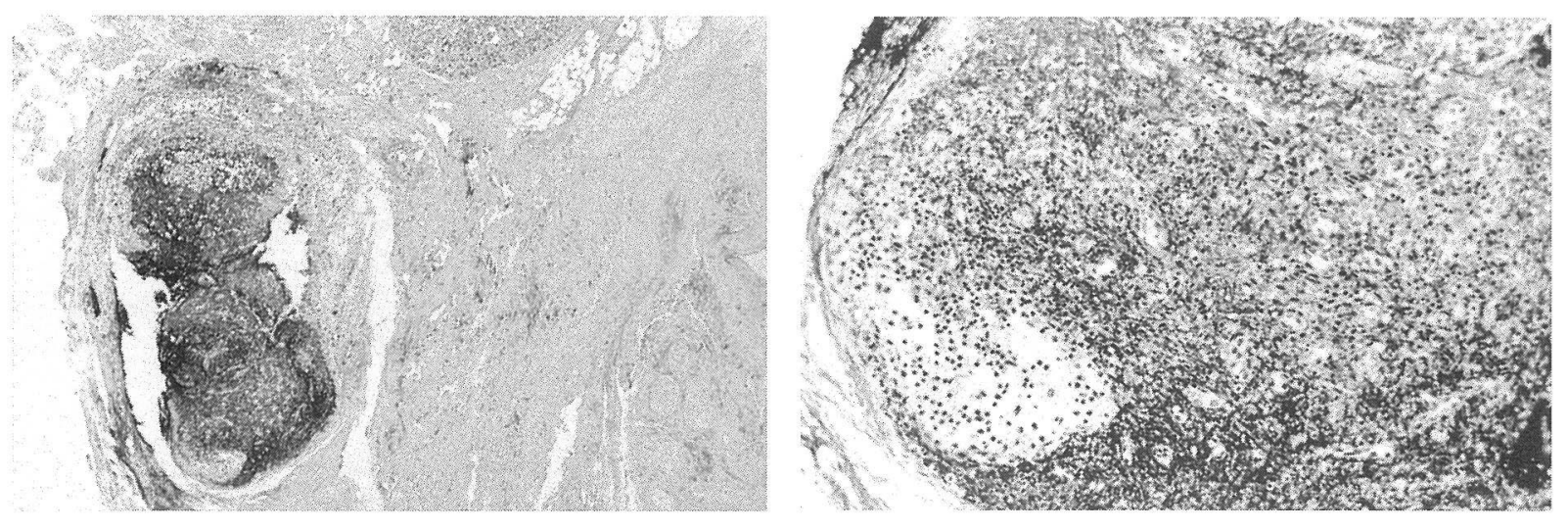

$\mathrm{b}$

図 2 症例 2

$\mathrm{a}$ : 画像所見 (左 : CT, 右 : US)

左：耳下部皮下に境界不明瞭な high density mass を認める.

右：皮下に境界不明瞭な hypoechoic mass を認める.

$\mathrm{b}$ : 病理組織像 (HE 染色. 左: 弱拡大, 右 : 強桩大)

左：腫瘍組織残存它認める。

右：粘液産生細胞と中間型細胞を認める.

るところであるが，初回手術時の腫瘍の大きさや局在， 組織型，初回手術の術式などにより決定することになる と思われる。千和ら ${ }^{8)}$ は $\mathrm{T} 2 \mathrm{a}$ では耳下腺浅葉切除術を

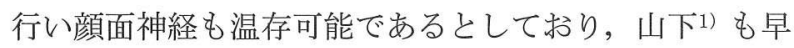
期癌の治療法として低悪性癌では顔面神経を温存し浅葉 切除を，中〜高悪性癌では耳下腺全摘術を行い顔面神経 は温存可能であると述べている。自験例のように初回手 術時の腫愓の大きさが $20 \mathrm{~mm}$ 以下で, 再手術までの期間
が 4 週以内と短い症例であれば早期の耳下腺癌の初回手 術と同様の方針で再手術を行えばよいと思われる。必ず しも耳下腺全摘が必要ではなく, 顔面神経も温存が可能 と思われる。自験例では 5 例中 4 例は浅葉切除で，また 5 例全例で顔面神経は温存され 5 年以上再発はみられず 生存中である. $\mathrm{N} 0$ 症例の予防的頸部郭清についても一定 の見解が得られていないのが現状であるが，自験例では 腫瘍径が $40 \mathrm{~mm}$ 大であった腺様囊胞癌の 1 例に保存的頸 
部郭清術を予防的に行ったが, 組織学的にリンパ節転移 は認なかった。 ほかの 4 例は腫瘍が $20 \mathrm{~mm}$ 以下の大きさ であり予防的郭清は行わなかったが，いずれも再発を認 めていないことから予防的郭清の必要性は少ないものと 考える1).

$$
\text { まとめ }
$$

1. 他院または他科で良性腫瘤として摘出術を受け術 後に悪性腫瘍と診断され, 当科で再手術を行った耳下腺 癌の 5 症例を報告した。

2. 男性 3 例, 女性 2 例で, 年齢は $10 \sim 77$ 歳, 平均年 齢は 40 歳であったが, 15 歳以下の小児例が 2 例認めら れた。

3. 病理組織型は, 腺様囊胞癌 2 例, 粘表皮癌 2 例, 腺 房細胞癌 1 例であり, 腺様囊胞癌の 1 例と粘表皮癌の 1 例は小児例であった。

4. 初回手術より 8 週以内に再手術を行った. 術式は耳 下腺全摘 1 例, 浅葉切除 4 例であり 5 例とも顔面神経は 温存した.

5. 当科受診時には, 触診上は局所に腫瘍の残存所見は 認めなかったが 5 例中 4 例に組織学的に腫瘍の残存を認 めた。

6. 術後経過は良好で1例も再発，転移を認めていない．

\section{参考文献}

1）山下敏夫：耳下腺早期癌の診断と治療. JOHNS $13: 613$ 617, 1997.

2）鈴木晴彦, 竹内洋介, 沼田 勉, 他 : 耳下腺腫瘍の超音波 診断. 日耳鼻 $100: 893 \sim 899,1997$.

3）海沼和幸, 坂口正範, 横山春樹, 他 : 唾液腺腫瘍に対する 穿刺吸引細胞針の有用性. 耳喉頭顓 68: $1035 \sim 1039,1996$.

4）田中一仁，増田正純，新田清一，他：唾液腺疾患の質的診 断に゙抢る穿刺吸引細胞診の検討. 日耳鼻 $101: 1283 \sim$ 1291，1998.

5）安松隆治, 一番ヶ瀬崇, 富田和英, 他：唾液腺腫瘍におけ る術前細胞診, 術中迅速組織検査の有用性. 頭頸部腫崵 26 : $6 \sim 11,2000$.

6）鮫島靖浩, 増山敬祐, 吉田 誠, 他：当科における耳下腺 癌の治療成績の検討. 口咽科 9:511 520, 1997.

7）安松隆治, 一番ヶ瀬崇, 富田和英, 他 : 耳下腺癌の臨床的 検討. 日耳鼻 $102: 883 \sim 890,1999$.

8）千々和圭一, 森 一功, 坂田一成, 他: 耳下腺悪性腫瘍の 治療成績. 耳鼻 $44: 351 \sim 359,1998$.

原稿受付: 平成15年 2 月 10 日

原稿採択: 平成15年 4 月 2 日

別刷請求先 : 桜井一生

テ470-1192 豊明市沓掛町田楽ヶ䆶1-98

藤田保健衛生大学医学部耳鼻咽喉科 